\title{
Getting Everyone to the Fair: Supporting Teachers in Broadening Participation in Science and Engineering Fairs
}

\author{
Joni M. Lakin ${ }^{1}$ (D) - Mary Lou Ewald ${ }^{2} \cdot$ Emily E. Hardy $^{3} \cdot$ Paul A. Cobine $^{4} \cdot$ Janie G. Marino ${ }^{2} \cdot$ Allen L. Landers $^{5}$. \\ Virginia A. Davis ${ }^{6}$
}

Accepted: 15 February 2021 / Published online: 12 March 2021

(C) The Author(s), under exclusive licence to Springer Nature B.V. 2021

\begin{abstract}
Science and Engineering (S\&E) fairs are a valuable educational activity and are believed to increase students' engagement and learning in science and engineering. However, due to differences in resources, many schools do not implement fairs to achieve these benefits for their students. This study reports the findings of a program intended to increase the participation of students from low-achieving and under-resourced schools in a regional fair program that feeds into the international fair competition. We found that the number of schools and projects participating in our regional fair increased dramatically since the start of the program. Teachers had mostly positive expectations for the project and expressed buy-in for the effort the project -would take. They recruited a diverse pool of students to participate in the school fairs. Quasi-experimental methods allowed us to explore the impact of completing S\&E fairs on student gains on science self-efficacy, interest and value perceptions. Controlling for pre-existing differences in these attitudes, we found that students not completing projects showed declines in their science attitudes during the year. Students who completed projects maintained similar attitudes, while those whose projects advanced to the regional fair had substantial gains on all three variables. It is unknown whether this gain can be attributed to the experience of engaging with a quality project, from being the kind of student who completes a quality project, or some other factor. Future research with greater experimental control could address these questions.
\end{abstract}

Keywords Scientific inquiry $\cdot$ Science fairs $\cdot$ Program evaluation

\section{Introduction}

The Next Generation Science Standards (NGSS,National Research Council, [NRC] 2013) state that students can only learn about scientific inquiry and the nature of science by

Joni M. Lakin

jlakin@ua.edu

1 Department of Educational Studies, University of Alabama, Tuscaloosa, AL 35487, USA

2 Office of Outreach, College of Sciences and Mathematics, Auburn University, Auburn, AL 36849, USA

3 Department of Chemistry and Biochemistry, Old Dominion University, 5115 Hampton Blvd, Norfolk, VA 23529, USA

4 Department of Biological Sciences, Auburn University, Auburn, AL 36849, USA

5 Department of Physics, Leach Science Center, Auburn University, AL 36832 Auburn, USA

6 Department of Chemical Engineering, Auburn University, 212 N Ross St, Auburn, AL 36830, USA 'directly experiencing those practices for themselves' (p. XV). Science and Engineering (S\&E) fairs provide these experiences by engaging students in authentic scientific practices and engineering design processes, as well as calling on students' creativity using inquiry-focused learning (Abernathy \& Vineyard, 2001; Bennett et al., 2018; Koomen et al., 2018; Paul et al., 2016; Sahin, 2013; Schmidt \& Kelter, 2017; Welsh et al., 2020). Proponents of $S \& E$ fairs argue this enhanced student interest leads to increased numbers of students studying and pursuing careers in science and engineering (Aubusson, 2012; Bencze \& Bowen, 2009; Schmidt \& Kelter, 2017).

The impetus for this project was an observation by the directors of a regional $S \& E$ fair that their participants and winners, who advanced to state and national competitions, consistently came from a small number of well-resourced schools with teachers who were experienced in the fair process. This is consistent with the literature showing that parent resources and school quality are associated with participation and success in these types of extracurricular program (Abernathy \& Vineyard, 2001; Korkmaz, 2012). 
It was clear that providing equitable access to the $\mathrm{S} \& \mathrm{E}$ fair opportunity was directly affected by teachers introducing S\&E fairs at the local level and their readiness (and insider knowledge) for mentoring students in completing projects. McComas (2011) called for better teacher preparation to help educators make S\&E fairs an effective and inclusive learning opportunity (see also Kook et al., 2020). There is limited literature around interventions focused on providing in-service teachers with the knowledge and skills to implement S\&E fairs in their schools in order to diversify the students participating in fairs and therefore accessing this opportunity to experience authentic scientific inquiry. ${ }^{1}$ The present research addresses this gap by studying the impact of a multi-year project focused on supporting teachers to implement a high-quality S\&E fair process in their home schools. We analysed impacts on students, teachers and the S\&E fair system more broadly to assess the success of this program and provide evidence that such an intervention for teachers is likely to have positive effects both on $\mathrm{S} \& \mathrm{E}$ fair programs and on the students those programs serve.

The goal of the project, and thus the focus of this research, was to improve the knowledge and skills of teachers in lower-resourced schools for implementing S\&E fair to ultimately have a positive effect on students' attitudes towards science and engineering. To evaluate the program's success, we were interested in the student-, teacher- and system-level impacts of the program. At the student level, we considered the positive impacts of S\&E fair participation on students' attitudes toward science and engineering. For teachers, we explored perceptions of S\&E fairs and their buy-in or motivation to participate before and after professional development (PD) experiences because teacher attitudes towards an intervention are vital to implementation (Harn et al., 2013). At the broader level, we were interested in issues of equity around S\&E fairs. In particular, we wanted to explore how well teachers recruited a diverse pool of S\&E fair participants and how this program impacted the quality and diversity of the regional S\&E fair to which students from the schools could advance as part of the competition process.

\section{Why S\&E Fairs?}

Inquiry-based science refers to students using their scientific knowledge, reasoning and skills to conduct investigations. Schwab and Brandwein (1966) developed the idea of inquiry-based science teaching so that students would have opportunities to learn how scientific knowledge is generated and to participate in the authentic practices of science. This approach to science education was fully entrenched with the

\footnotetext{
1 One intervention we located after conducting our study was carried out with teachers in Turkey (Akçöltekin, 2016).
}

introduction of the NGSS (NRC, 2013) and the Framework for K-12 Science Education (NRC, 2012). The NGSS framework includes scientific and engineering practices as one of its three key dimensions for science learning. The term 'scientific practices' was introduced to provide more guidance and structure to the concept of inquiry. These practices include the skills, reasoning abilities and content knowledge that are necessary for students to engage in investigations about the natural world (NRC, 2013).

Inquiry can be further understood through Duschl's (2008) three facets of inquiry, which they argue should be present in the science classroom (also discussed in Furtak et al., 2012). These three facets are conceptual structures (related to the disciplinary knowledge of NGSS), epistemic frameworks (which are the strategies and skills used in a scientific investigation) and the social aspects of science, including collaboration and communication of findings. A comprehensive meta-analysis (Furtak et al., 2012) as well as a research synthesis (Minner et al., 2010) have both provided support to the claim that inquiry-based learning, particularly when it includes all three of Duschl's facets, is more effective than traditional, structured learning. In particular, Furtak et al. (2012) found that science education interventions that engaged more of these facets had greater effects on student learning.

$\mathrm{S} \& \mathrm{E}$ fair projects can represent true open inquiry in the science classroom and reflect all of Duschl's (2008) facets of inquiry. ${ }^{2}$ To address the conceptual structures, students engage their scientific knowledge in selecting their project topics and interpreting their findings. Rarely in formal science education is such a level of freedom possible or practical. Second, students use scientific ways of knowing (i.e., epistemology) in designing their investigations and carrying out data collection and analysis. This allows students to engage in meaningful and authentic scientific practices, exemplifying the practices aspect of the NGSS. Finally, the social aspects of communication and collaboration are achieved during the preparation of the projects, particularly when projects are done in groups, as well as during the fairs when students communicate results with peers and adults during viewing and judging.

\section{Impacts of S\&E Fairs on Students}

Although there is limited direct evidence of knowledge gains from S\&E fairs (Aubusson et al., 2012; Yasar \& Baker, 2003), there are positive indications. Students

\footnotetext{
$\overline{2}$ We should note that 'canned' experiments and demonstration are too common in many S\&E Fairs. These do not engage authentic inquiry where students must pose a scientific question and collect and analyse data to address it.
} 
report that they learned more about the scientific process and engineering design after completing an S\&E fair project (Grant, 2007; Schmidt \& Kelter, 2017). In addition, research study on group-based, self-selected engineering projects (Wilson-Lopez et al., 2018) found encouraging evidence of the potential for such projects to help students to acquire and enact a variety of problem-solving skills and science and engineering knowledge in meaningful ways.

The science education field is also increasingly recognizing the important role of affect and attitudes towards learning, including interest, utility-value and self-efficacy for the domain (Fortus, 2014; Guo et al., 2017; Wigfield \& Eccles, 2000). Evidence suggests that S\&E fairs improve students' attitudes towards science and engineering. For example, Grinnell et al. (2020) found that students who completed an S\&E fair project, under certain conditions, ${ }^{3}$ reported increased interest in science and engineering. Beier et al. (2019) studied the impact of project-based learning in undergraduate students and found that having these experiences increased their STEM career aspirations, perceptions of the value of STEM courses and enhanced their perception of their STEM skills.

The competition aspect of S\&E fairs may also be important. Miller et al. (2018) found that even when controlling for initial interest in STEM fields, students who participated in more STEM-related competitions had greater interest in a STEM-related career at the end of high school. Importantly, they also found that the interest was domain specific. Thus, the opportunity to select the topic of inquiry and to delve into a narrow STEM domain, possibly increasing students' self-efficacy or utility-value perceptions, may be another positive feature of S\&E fairs that is not available in other types of STEM competitions.

In addition to looking for gains in relevant attitudes towards science and engineering, we wanted to explore whether students felt that their S\&E fair projects were important experiences rising above their typical learning experience. In fact, many students report $\mathrm{S} \& \mathrm{E}$ fairs as being transformative experiences either at the time or reflecting as an adult (Welsh et al., 2020; Yoho, 2015). Thus, we also surveyed students about the degree to which their project was a transformative experience, a concept in learning popularised by Pugh (2011), referring to learning experiences that lead to powerful shifts in students' knowledge or views of a field. The transformative experiences scale (Pugh et al., 2010) was designed around three types of changes to students that result from transformative experiences: motivated use (including looking for opportunities to learn more about the topic), expanded perception (noticing connections of the

\footnotetext{
${ }^{3}$ Some of the conditions included making the projects optional and having teacher support in completing the project.
}

topic to everyday life) and experiential value (a sense that they have learned something important). Only students who completed a project completed this survey.

\section{S\&E Fair Implementation and Equity}

Researchers such as Cuevas et al. (2005) highlight the importance of extending inquiry-based learning to students from historically marginalised groups. This research has shown that teachers must be supported in their use of appropriate inquiry-based instruction with these students (Lee et al., 2004). Our study seeks to extend the research specifically on S\&E fairs as a pathway to meaningful inquiry-based learning and discusses teacher-focused PD designed to increase access to S\&E Fairs among students from historically marginalised groups.

A common public perception of S\&E fairs is that students who win have parents actively involved in the project or have greater resources (Craven \& Hogan, 2008; Grote, 1995; Syer \& Shore, 2001). Studies show that, in many cases, students must rely heavily on parental resources and knowledge to design a successful project (Grinnell et al., 2018; Hampton \& Licona, 2013). This means that better resourced students will tend to get greater benefits from S\&E fair participation. Further, when schools do offer S\&E fairs, they are often optional, which means that students with greater pre-existing interest in science or engineering are more likely to participate. As a result, schools with a high proportion of students from low socioeconomic status (SES) families are less likely to implement such a program for their students, despite the potential benefits (Bencze \& Bowen, 2009).

In addition to the demands placed on families, S\&E fairs put considerable demands on teachers (Bunderson \& Anderson, 1996; Craven \& Hogan, 2008; Wartinger, 1999). Organising such an event is especially demanding in the first few years of implementation. Teacher beliefs and attitudes towards an intervention are important to assess when a program wants to understand which teachers will implement the intervention with fidelity (Century et al., 2010; Harn et al., 2013; Lakin \& Shannon, 2015; O'Donnell, 2008). This led to our focus on teacher attitudes towards S\&E fairs and not simply on their implementation of the fairs.

Teachers' attitudes towards interventions can be parsed in numerous ways, but our previous work (Lakin \& Shannon, 2015) demonstrated the value of measuring teachers' attitudes toward the intervention's acceptability and effectiveness to predict whether they will invest the time and effort to implement an intervention with fidelity (see also Mowbray et al., 2003; O'Donnell, 2008). Acceptability is the perceived appropriateness, fairness or reasonableness of a treatment to address a particular need (Kazdin, 1980; Reimers et al., 1987; Tanol, 2010). Effectiveness is 
the perception that the intervention will have the intended positive impacts on the problem. We assessed these perceptions of S\&E fairs as part of our evaluation of the program (Century et al., 2010).

\section{The STEM-IQ Program}

To address observations of local inequities in S\&E fairs, a project called 'STEM-IQ: Science Technology Engineering and Mathematics Inquiry for Enhancing Science Education in Eastern Alabama' was developed that focused on introducing S\&E fairs to high-needs and low-achieving schools as a means for improving science interest and achievement. It was led by faculty and staff involved with the Greater East Alabama Regional Science and Engineering Fair (GEARSEF), a fair that is affiliated with the Regeneron International S\&E Fair (ISEF) system. All participating schools were located in the geographic area that is eligible to advance to GEARSEF as well as state and international competition.

The program focused on schools located in the Alabama Black Belt, an agricultural region that is historically low SES and has a large African American population. The districts this program served were primarily those that were under-resourced and with high levels of free or reduced lunch (FRL) eligibility. Based on information gathered while running a regional $\mathrm{S} \& \mathrm{E}$ fair, schools with higher poverty rates and fewer school resources are less likely to hold school-level fairs at all. When these schools do hold fairs and send students to the regional competition, the projects are noticeably lower in quality and less inquiry-based compared with students who come from better-resourced schools or who come from higher income families.

The project goals included enhancing (a) the regional fair by raising the rigor of the current $S \& E$ fairs and increasing the number of projects in the region, (b) impacts on schools by creating a sustainable $S \& E$ fair infrastructure and cultivating a culture of STEM promotion through the implementation of S\&E fairs and (c) student outcomes by increasing the diversity of students participating at the school and regional level and increasing individual students' science and engineering attitudes.

The PD for teachers in the program focused on support the access all students had to participating in the S\&E program. Our focus was on equitable access and addressing inequities the leadership noted in terms of (1) lower-resourced (or lower SES) schools not implementing S\&E Fairs, (2) teachers in higher-resourced districts having 'insider knowledge' that advantaged their students and (3) students in lower resourced schools not having the experiences to spark high-quality project ideas or not having access to the equipment to carry out investigations.
The PD involved hands-on learning experiences for teachers, analysis of successful student projects and opportunities to attend regional, state and international fairs. Co-learning was an important feature of the PD as teachers were recruited in 'vertical teams', which included two to three middle school teachers, two to three high school teachers and one administrator from the same school district. This arrangement was intended to promote within-school and cross-school support for student mentoring and S\&E fair development.

Teachers at remote rural schools noted that their students had fewer opportunities for guest speakers or site visits that might spark their interest in a STEM topic. Therefore, the project developed a program called Destination STEM, a day-long outreach event designed for grades 6-12. At this event, university faculty and graduate students presented science and engineering topics intended to spark interest and possible project ideas in the grade 6-12 students who attended.

During the school year, program-affiliated university faculty, staff and graduate students were available for more informal interactions with teachers and students. This included school visits at the invitation of teachers and assisting with judging at school-level fairs. As part of these interactions, teachers were provided with constructive feedback from the project member. Faculty were also available as mentors to teachers and directly to students completing S\&E fair projects, when requested.

The program was designed and implemented by a project team consisting of four science and engineering faculty members as well as staff from the College of Science and Mathematics (COSAM) Outreach office. All of the faculty and staff had extensive experience running the regional S\&E fair program. Most of the faculty served as head judges each year at this event. One faculty member (first author) from the College of Education served as external evaluator for the program. Outreach staff and graduate students, in collaboration with four to seven science and engineering faculty (depending on the year), provided the PD experiences and resources.

The project team continuously refined the training and support provided for each new cohort over the course of the grant. An outline of each year's topics and goals in the fully realised program are outlined in Table 1 . The final iteration of the program, as provided to cohorts 2 and 3 , consisted of a week-long summer workshop in the first year of participation. At this workshop, teachers received over $30 \mathrm{~h}$ of PD related to organising an S\&E fair. The workshop also focused on supporting teachers in implementing inquiry methods to support high-quality $\mathrm{S} \& \mathrm{E}$ projects that follow authentic science and engineering practices. In year 2 of their participation, each cohort returned for a 2-day workshop that provided additional training on needed or 
Table 1 Program activities for teachers and training topics by year of participation

\begin{tabular}{|c|c|c|c|}
\hline & Year 1 & Year 2 & Year 3 \\
\hline Training opportunities & $\begin{array}{l}\text { Five-day summer training } \\
\text { One-day workshop in fall } \\
\text { Attend GEARSEF, option to attend } \\
\text { state fair }\end{array}$ & $\begin{array}{l}\text { Two-day summer training } \\
\text { One-day workshop in fall } \\
\text { Attend GEARSEF, option to attend } \\
\text { state fair or international fair }\end{array}$ & $\begin{array}{l}\text { One-day workshop in fall (optional) } \\
\text { Attend GEARSEF, option to attend } \\
\text { state fair or international fair }\end{array}$ \\
\hline Goals for teacher participation & $\begin{array}{l}\text { Mentor at least two students in } \\
\text { completing a S\&E fair project, } \\
\text { bring projects to GEARSEF }\end{array}$ & $\begin{array}{l}\text { Mentor at least ten students in } \\
\text { completing a S\&E fair project, } \\
\text { organise a class- or school-level } \\
\text { fair, bring projects to GEARSEF }\end{array}$ & $\begin{array}{l}\text { Mentor at least ten students in } \\
\text { completing a S\&E fair project, } \\
\text { organise a class- or school-level } \\
\text { fair, bring projects to GEARSEF }\end{array}$ \\
\hline \multicolumn{4}{|c|}{ Workshop topics during summer training } \\
\hline Organisation of S\&E Fairs & $\begin{array}{l}\text { International S\&E Fair (ISEF) } \\
\text { organisation } \\
\text { Requirements for running an ISEF } \\
\text { program, managing paperwork } \\
\text { Project oversight (behavioural, } \\
\text { bacteria, vertebrate and chemical } \\
\text { risk assessments) } \\
\text { Developing mission statements and } \\
\text { goals } \\
\text { How do judges evaluate a project? }\end{array}$ & $\begin{array}{l}\text { Recap from last year-what have } \\
\text { we learned/what have YOU } \\
\text { learned } \\
\text { Trouble-shooting and common } \\
\text { issues } \\
\text { Behavioural science survey projects } \\
\text { and IRBs } \\
\text { Strategies for recruiting and train- } \\
\text { ing local judges } \\
\text { Vertebrate animals/bacteria/risk } \\
\text { assessment }\end{array}$ & No formal training in year 3 \\
\hline Guiding student projects & $\begin{array}{l}\text { Writing a testable hypothesis and } \\
\text { research question } \\
\text { Improving science literacy skills } \\
\text { Developing appropriate research } \\
\text { plans } \\
\text { Preparing students for the judges' } \\
\text { interviews }\end{array}$ & $\begin{array}{l}\text { Selling your project-how to tell } \\
\text { your experiment story } \\
\text { Refining the research plan }\end{array}$ & \\
\hline Technical skills & $\begin{array}{l}\text { Data analysis skills } \\
\text { Research posters and backboards } \\
\text { Ideas for physical science and } \\
\text { engineering projects }\end{array}$ & $\begin{array}{l}\text { Sterile lab techniques on a budget } \\
\text { Poster printing for more profes- } \\
\text { sional presentations } \\
\text { Data analysis: basic statistics and } \\
\text { reporting }\end{array}$ & \\
\hline Classroom supports & $\begin{array}{l}\text { Activities to introduce potential } \\
\text { project topics } \\
\text { Starting successful projects-grad- } \\
\text { ing rubrics } \\
\text { Pacing guides for mentoring } \\
\text { projects } \\
\text { Hands on activities and virtual labs } \\
\text { Standards alignment }\end{array}$ & $\begin{array}{l}\text { Station rotation-sharing tangibles } \\
\text { for building your resources }\end{array}$ & \\
\hline
\end{tabular}

requested topics. For each cohort, year 3 included continued informal support from the program with goals for mentoring at least 10 student projects. No formal training was planned for these teachers, but many chose to attend the program events during the year.

\section{This Study}

The goal of the STEM-IQ project was to expand the adoption of S\&E fairs in local schools with high proportions of lowSES students. Although we strongly encouraged teachers to make projects mandatory, many teachers made participation optional or only incentivised participation, such as providing extra credit. As a result, we had the opportunity to explore which types of students, based on demographics, were more likely to complete projects. We were also able to explore the impacts of fair participation on students' attitudes towards science when controlling for demographic characteristics and pre-existing science interest using ANCOVA methods. Our research questions addressed each level of the program (teachers and schools) as well as the impact of S\&E fairs on students:

1. Was there a substantial increase in the overall number of projects as well as the number of students from underrepresented groups (female, Latinx, African American) who competed and/or won awards at the regional fair?

2. Do teachers hold the attitudes and beliefs that will support their implementation of perceive S\&E fairs? 
Table 2 Survey scales for teachers (scale: $0=$ Not at all true, $2=$ Somewhat true, $4=$ Very true)

\begin{tabular}{|c|c|c|c|}
\hline Survey scales & Sample survey items & No. of items & Cronbach's $\alpha$ \\
\hline $\begin{array}{l}\text { Acceptability of the program } \\
\text { and for S\&E fairs in general }\end{array}$ & $\begin{array}{l}\text { Our school has enough staff, time, and other resources to make the STEM-IQ } \\
\text { Project benefit the school } \\
\text { Our school has enough staff, time and other resources to make a science and engi- } \\
\text { neering fair benefit the students } \\
\text { Organising a science and engineering fair for my class or school is worth the time } \\
\text { it takes to organise } \\
\text { I believe I will take away lasting benefits from participating in the STEM-IQ } \\
\text { Project }\end{array}$ & 8 & .68 \\
\hline Expected benefits for students & $\begin{array}{l}\text { I think completing Science and Engineering fair Projects will help me increase .... } \\
\text { students' competence in science } \\
\text { students' motivation to understand science in depth } \\
\text { students' interest in science } \\
\text { students' belief in the importance of science } \\
\text { students' academic performance in science } \\
\text { female students' interest in science } \\
\text { racial/ethnic minority students' interest in science }\end{array}$ & 7 & .91 \\
\hline Intent to implement & $\begin{array}{l}\text { I will mentor students this year } \\
\text { I will implement a science and engineering fair at my school this year }\end{array}$ & 2 & NA \\
\hline
\end{tabular}

3. How did background characteristics relate to students' likelihood of participating in the school fair? Advancing to the regional fair?

4. Controlling for pre-fair differences, did students who participated in a school fair show increased science interest, value or self-efficacy? What kinds of transformative experiences (Pugh et al., 2010) did students who completed projects report?

\section{Methods}

\section{Regional Fair}

All participating schools came from the region of Alabama that participates in the GEARSEF regional fair that accepts projects from school-level fairs; GEARSEF winners and highly scored projects advance to the Alabama State Science and Engineering Fair and potentially to the International Science and Engineering Fair. The coauthors of this paper are all involved in the administration of GEARSEF and have access to program records. As part of the study, GEARSEF records were mined for information about the number of projects completed each year, starting prior to the grant period in 2013. We also collected information on the number of girls and students from underrepresented minority groups (specifically Latinx or African American) who competed in the regional fair and/or received an award for their project at the GEARSEF competition. Descriptive statistics based on these data will answer the first two research questions.

\section{Teachers}

Our data collection methods included quantitative surveys completed by teachers related to perceptions of $\mathrm{S} \& \mathrm{E}$ fairs. The project's evaluator (first author) compiled survey measures of teachers' attitudes and evaluation of program activities. See Table 2. These surveys were partly based on previous evaluations (particularly a Math-Science Partnership [MSP]; Lakin \& Wallace, 2015) and assess buy-in to the program and intent to implement program activities. Specifically, we measured teacher attitudes as 'buy-in' which includes the acceptability of the intervention (both S\&E Fairs as well as the STEM-IQ initiative) relative to the time and other resources it requires. We also surveyed teachers on their perceptions of effectiveness of the intervention, which is also shown to predict teacher implementation when they believe the intervention will have important impacts on their students.

Because our program evolved through the Cohort 1 process (2014-2016), this study reports the findings from teachers and students who participated in Cohort 2 (2015-2017) and 3 (2016-2018) of the program. At the start of the program, teachers completed baseline surveys with demographic questions. We received 30 survey responses, with 2 declining to complete the full survey, but providing demographic information. See Table 3.

Across cohorts, the teachers served a range of grade 6-12 students and taught either a self-contained classroom or were science or mathematics specialists. The teachers had a median of 11 years of teaching experience and most had been in their current school for at least 4 years. When asked 
Table 3 Teacher demographic characteristics

\begin{tabular}{llll}
\hline & & $\begin{array}{l}\text { Cohort 2 } \\
(2015-2017)\end{array}$ & $\begin{array}{l}\text { Cohort 3 } \\
(2016-2018)\end{array}$ \\
\hline $\mathrm{N}$ & & 18 & 14 \\
Average years of teaching experience & 11 & 11.3 \\
Gender & Female & 14 & 13 \\
& Male & 4 & 1 \\
Race & African American & 2 & 2 \\
& Biracial & 1 & 0 \\
& White & 15 & 9 \\
Degrees held & Not reported & 0 & 3 \\
& Bachelor's only & 4 & 2 \\
& Bachelor's plus & 3 & 1 \\
& graduate credits & & \\
& Master's & 10 & 5 \\
& Specialist & 1 & 0 \\
& Doctorate & 0 & 1 \\
& Not reported & 0 & 5 \\
\hline
\end{tabular}

about the typical performance level of their students, teachers reported that their students either had a range of achievement levels or were at or below grade level; just one reported their students were mostly performing at grade level.

When asked about their personal experience with science and engineering fairs, most had never participated in science fairs as students (about 80\%). Two-thirds of Cohort $2 \mathrm{had}$ experience organising a class-level or school-level fair. In Cohort 3, just a few had prior experience organising a fair. All analyses for teachers involved descriptive statistics.

\section{Students}

Teachers administered pre- and post-fair surveys of science/engineering and fair-related attitudes to students in their science classes that included both students who did and did not complete S\&E projects. Students who did not complete a project were considered the control group. Across 2 years, 32 teachers from the two cohorts provided post-fair survey data from participating and non-participating students. We received data from 1257 students at the beginning of the year, but just 982 at the end of the year. Our matching efforts identified 795 complete cases, which is the data we focus on here. Students provided demographic information about themselves, including gender and race or ethnicity (See Table 4). We also asked the student about their current level of performance in science class (options: Worse than most other students, About the same as other students, Better than other students, Don't know). We also asked about their mother's (or other adult female living with you) and father's (or other adult male living with you) education levels with options of did not complete high school, completed high school, completed college and completed an advanced degree. Given the limited numbers of students reporting parents had less than high school or an advanced degree, we collapsed these categories into 'high school degree or less' and 'college or advanced degree'.

Measures of science attitudes (value and self-efficacy for science) as well as science and engineering interest were drawn from the MSP-MAP project (Karabenick \& Maehr, 2007) that developed theoretically grounded measures of constructs likely to be impacted by grades $6-12$ science interventions. See Table 5. Previous research with these scales had strong internal consistency ( $\alpha=.88$ to .95 ; Conley et al., 2006). Our internal consistency estimates were lower but still acceptable $(\alpha=.72-.93)$.

We also asked questions about whether students found S\&E fair projects to be 'transformative experiences' (Pugh et al., 2010) which are expected to reflect deeper engagement with science. We shortened the scales for time, selecting four representative items from each scale: motivated use (reflects whether students seek opportunities to learn more), expanded perception (degree to which connect their learning outside of the classroom) and experiential value (beliefs that the learning is useful). We also rephrased each question to ask about the fair project specifically. The scale is intended to be adapted to the specific application under study (Koskey et al., 2018). The original scales correlated $r=0.5$ to 0.7 with measures of utility-value (Koskey et al., 2018), which demonstrates acceptable discriminant as well as predictive value. Only students completing a project responded to the questions about their transformative experience ( $n=499$ for these analyses). We found that the scales had acceptable internal consistency $(\alpha=.81$ to .84$)$ and correlated with values ( $r=.39$ to .44$)$ with a strength similar to previous work. A confirmatory factor analysis supported the use of three factors rather than a single composite score.

We used logistic regression to determine if other demographic variables predicted participation or advancing to the regional fair. These demographic variables included sex, parent education level (divided into high school degree or less compared with college or advanced degrees), current academic performance ("worse than most other students', 'about the same' or 'better than some other students') and race/ethnicity (Latinx, African American, Asian, Multi-racial, white).

To compare student changes as a result of S\&E fair participation or non-participation, we contrasted three groups of students: those who did not complete a project, those who completed a project but did not advance to the regional fair and those who did advance to the regional 
Table 4 Student demographic characteristics

\begin{tabular}{|c|c|c|c|}
\hline Variable & & Frequency & Percent \\
\hline \multirow[t]{3}{*}{ Fair participation } & No project & 249 & 31.4 \\
\hline & Project, did not advance & 464 & 58.4 \\
\hline & Project, advanced & 82 & 10.3 \\
\hline \multirow[t]{8}{*}{ Grade level } & 6 & 146 & 18.4 \\
\hline & 7 & 82 & 10.3 \\
\hline & 8 & 144 & 18.1 \\
\hline & 9 & 178 & 22.4 \\
\hline & 10 & 31 & 3.9 \\
\hline & 11 & 141 & 17.7 \\
\hline & 12 & 67 & 8.4 \\
\hline & Missing & 6 & 0.8 \\
\hline \multirow[t]{7}{*}{ Race or ethnicity } & African American & 286 & 36.0 \\
\hline & Hispanic & 44 & 5.5 \\
\hline & Asian & 13 & 1.6 \\
\hline & White & 391 & 49.2 \\
\hline & Mixed & 58 & 7.3 \\
\hline & Other & 1 & 0.1 \\
\hline & Missing & 2 & 0.3 \\
\hline \multirow[t]{3}{*}{ Gender } & Female & 441 & 55.5 \\
\hline & Male & 347 & 43.6 \\
\hline & Missing & 13 & 1.7 \\
\hline \multirow{4}{*}{$\begin{array}{l}\text { Science class performance } \\
\text { (compared to peers) }\end{array}$} & About the same as other students & 360 & 45.3 \\
\hline & Better than other students & 259 & 32.6 \\
\hline & Don’t know & 145 & 18.2 \\
\hline & Worse than most other students & 25 & 3.1 \\
\hline \multirow[t]{3}{*}{ Father's education } & High school degree or less & 352 & 44.3 \\
\hline & College or advanced degrees & 397 & 49.9 \\
\hline & Missing & 46 & 5.8 \\
\hline \multirow[t]{3}{*}{ Mother's education } & High school degree or less & 294 & 37.0 \\
\hline & College or advanced degrees & 490 & 61.6 \\
\hline & Missing & 11 & 1.4 \\
\hline
\end{tabular}

fair. We then ran ANCOVA analyses looking at the effect of participation in the S\&E fair controlling for pre-fair attitudes within each type of attitude (interest, self-efficacy and attitudes). We included classroom as a random-effects variable to control for the clustering effects of students nested in classrooms. We also compared students who did and did not advance to GEARSEF in terms of their perception of having transformative experiences. For this, we used independent-sample $t$ tests.

\section{Results}

The first part of the study involved effects observed at the regional level using program records, specifically if there was an increase in regional fair participation or the diversity of students competing or winning awards at the fair. We found that the number of schools and projects participating in the fair increased dramatically from 9 schools in 2013 to a maximum of 40 schools in 2018. See Fig. 1, which shows that the number of schools participating in the regional fair has risen from 9 schools prior to the program (2013) to 40 schools in 2018, the year that cohort 3 completed their formal participation. Even after direct funding for teachers ended (2018), the following years saw 36 and 31 schools participate in the regional fair. ${ }^{4}$ Similarly, the number of projects rose from 63 projects to 276 and maintained around 200 projects after teacher funding ended. See Fig. 2. The number of projects presented at the fair is a function of the number of schools participating (because each is allowed to advance up to $20 \%$ of their projects)

\footnotetext{
4 The 2020 fair took place prior to most school closures due to the COVID-19 pandemic, but some schools had begun to restrict offcampus activities.
} 
Table 5 Student survey scales and internal consistency estimates (scale: $0=$ Not at all true, $2=$ Somewhat true, $4=$ Very true)

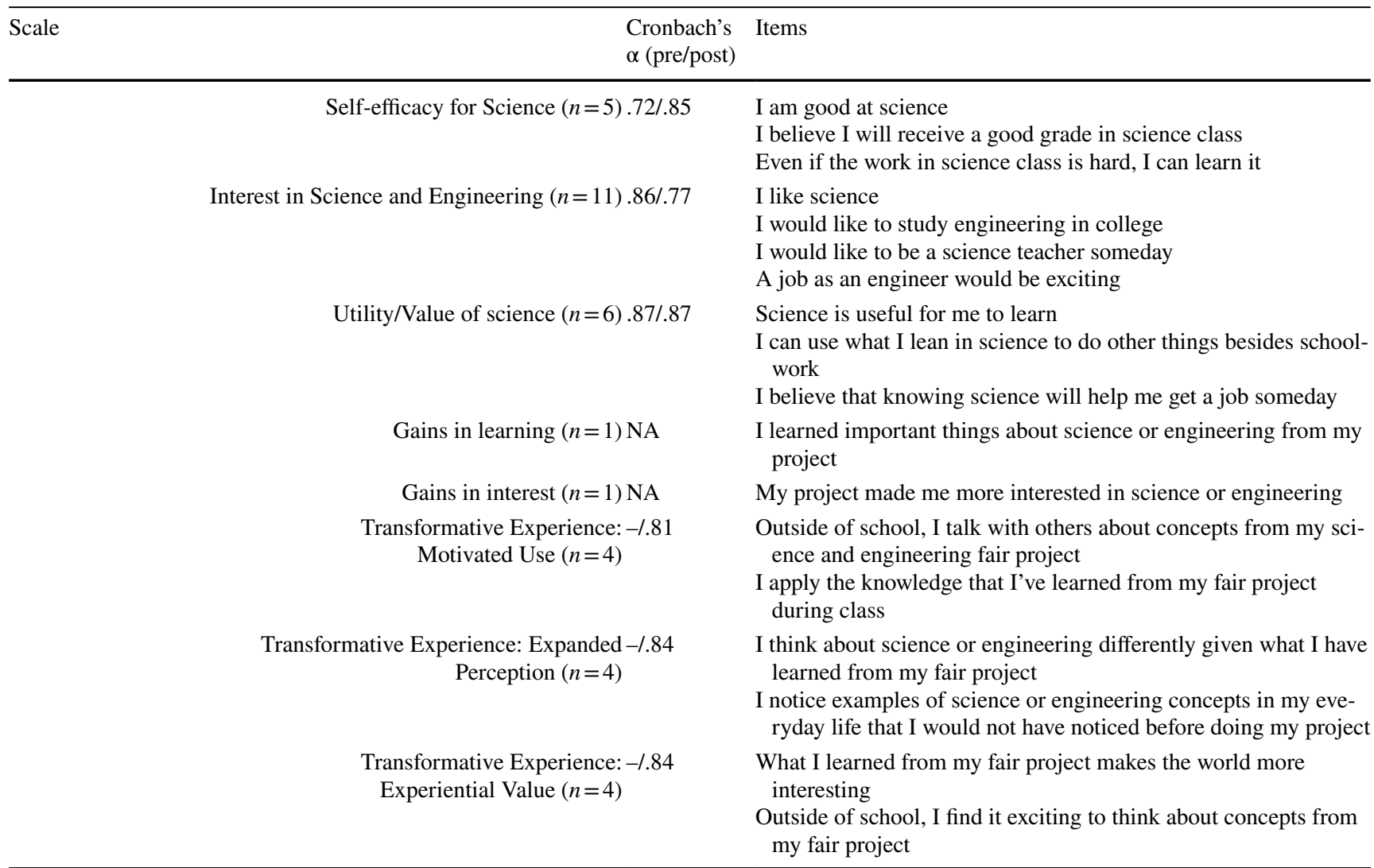

Transformative experience scales administered at post-test only

and a function of quality, because judge ratings must meet a score minimum (set by each school) to advance. Apart from the current project, there were no additional initiatives promoting adoption of S\&E fairs, so we can safely attribute much of this increase to the program.

Another important program result was the increase in the diversity of the science fair winners in the region. Figure 3 shows the demographics of the overall fair as well as students receiving category and special awards. Category awards are based on topic, such as engineering, physics or behavioural science topics. Special awards are funded by organisations and can have specific targets (such as the named award for water-related projects). Overall, the demographics of the fair did not change much $(68 \%$ white in 2013 to $64 \%$ white in 2020). However, substantially more African American students received category and special awards after program implementation (increasing by $17 \%$ and $6 \%$, respectively), suggesting students from these demographic groups were bringing higherquality projects to the fair. Note also that the 2013 fair had much less participation (74 students in 2013 vs. 170 in 2020), so there were many more students participating and winning awards in 2020 .

\section{Teacher Attitudes and Beliefs to Support Implementation}

Our second research question focused on teachers' attitudes and beliefs that would support their implementation of an S\&E Fair. Acceptability and perceived effectiveness are important factors in teachers' implementation of a new program (Lakin \& Shannon, 2015). Thirty teachers completed the beginning and end-of-workshop survey during their first summer of participation that asked about their attitudes towards the program as well as for $\mathrm{S} \& \mathrm{E}$ fairs in general; see Table 6 .

Teachers had mostly positive expectations for the project and expressed perceptions of acceptability $(M=3.7$ [max. $=4], S D=0.4)$ and effectiveness $(M=3.4, S D=0.5)$ for the project and S\&E fairs. This is not surprising as we presume that mostly teachers who were amenable to S\&E Fairs would participate. However, their buy-in after training was still important to understand to see if they had reservations. Indeed, teachers expressed the weakest agreement with the statement that their school had enough resources to make the most of the STEM-IQ project $(M=3.3, S D=0.5)$, or of the $\mathrm{S} \& \mathrm{E}$ fair itself $(M=3.3$, $S D=0.6)$. While nearly all teachers expressed confidence 
Fig. 1 The number of schools participating in GEARSEF from 2013 (pre-STEM-IQ) to 2020 (teacher incentives ended before the 2019 fair)

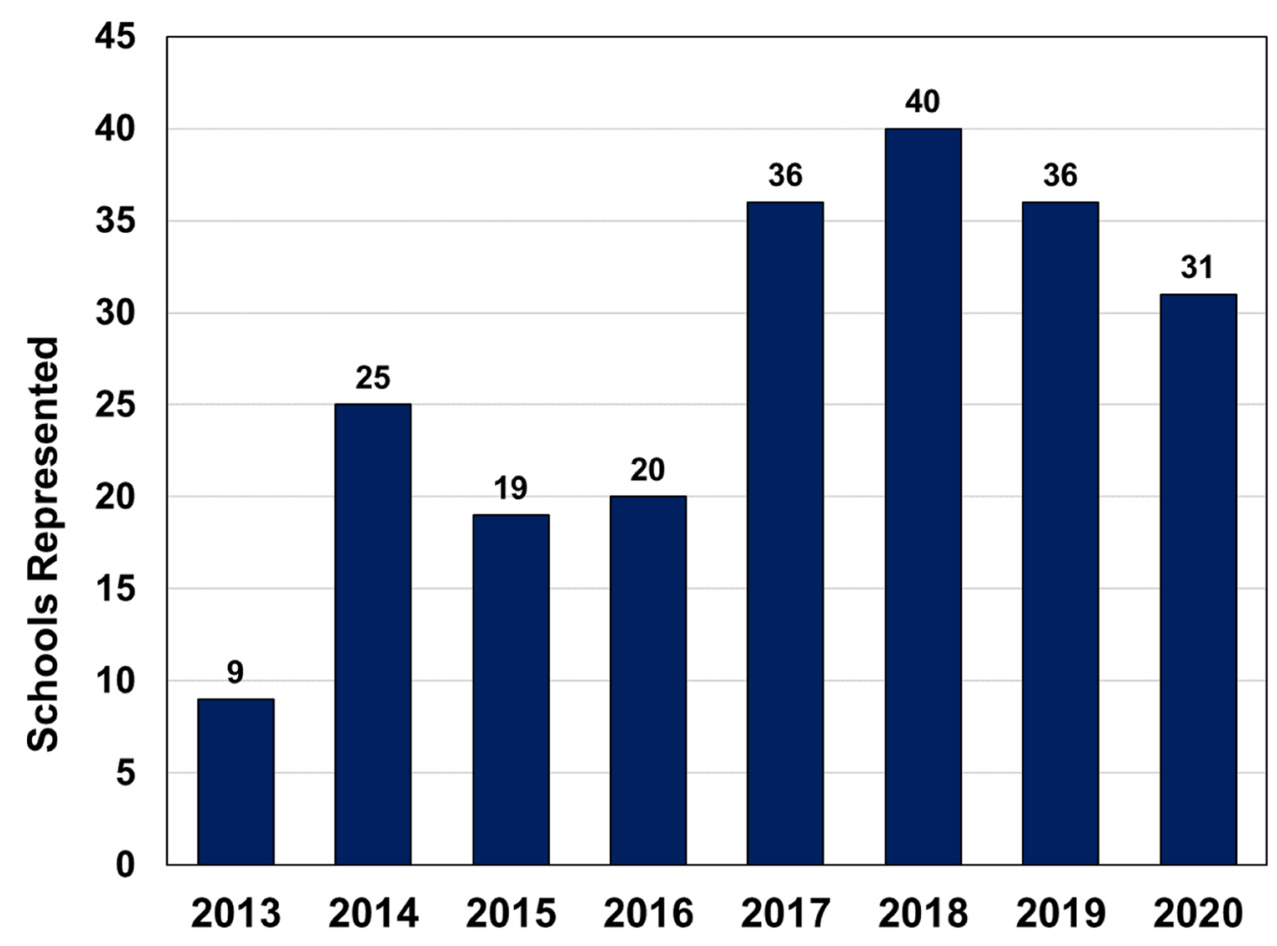

they would mentor projects and implement a school fair in the coming year (intent to implement, $M=4.0, S D=0.2$ ), these survey results suggest that teachers were concerned that the fair would take a good deal of time and resources to be implemented effectively.

Teachers were optimistic that the S\&E fairs would help their students develop competence, motivation, interest and belief in the importance of science (effectiveness, $M=3.4$, $S D=0.5)$. There was somewhat more variability $(S D=0.7$ or 0.8 ) in their perceptions that the fairs would specifically benefit girls or racial/ethnic minority students in their interest in science.

\section{Diverse Student Participation in S\&E Fair}

Our first research question regarding students focused on the diversity of students who participated in the school S\&E fair to explore how effective the teachers were at engaging
Fig. 2 The number of student projects competing in GEARSEF from 2013 (preSTEM-IQ) to 2020 (teacher incentives ended before the 2019 fair)

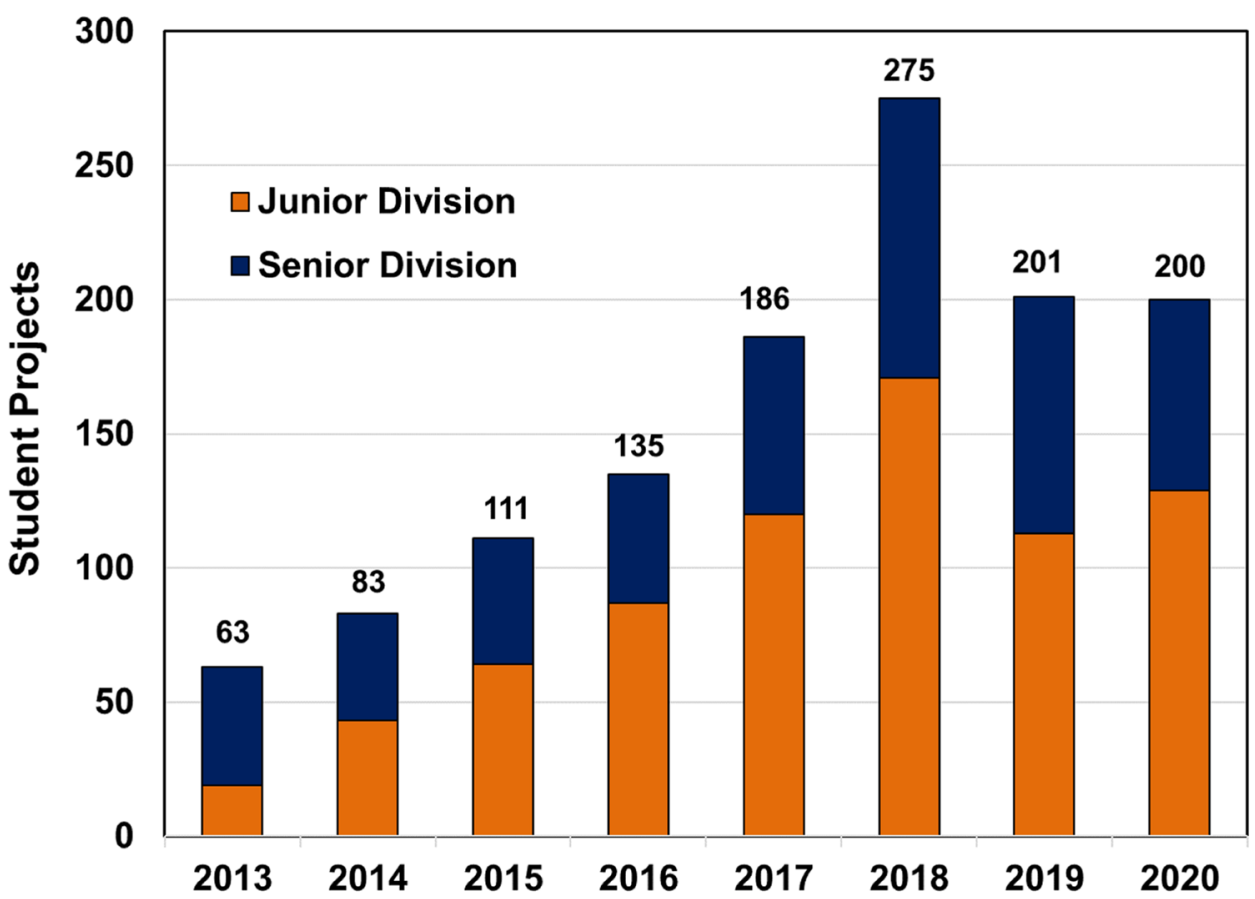




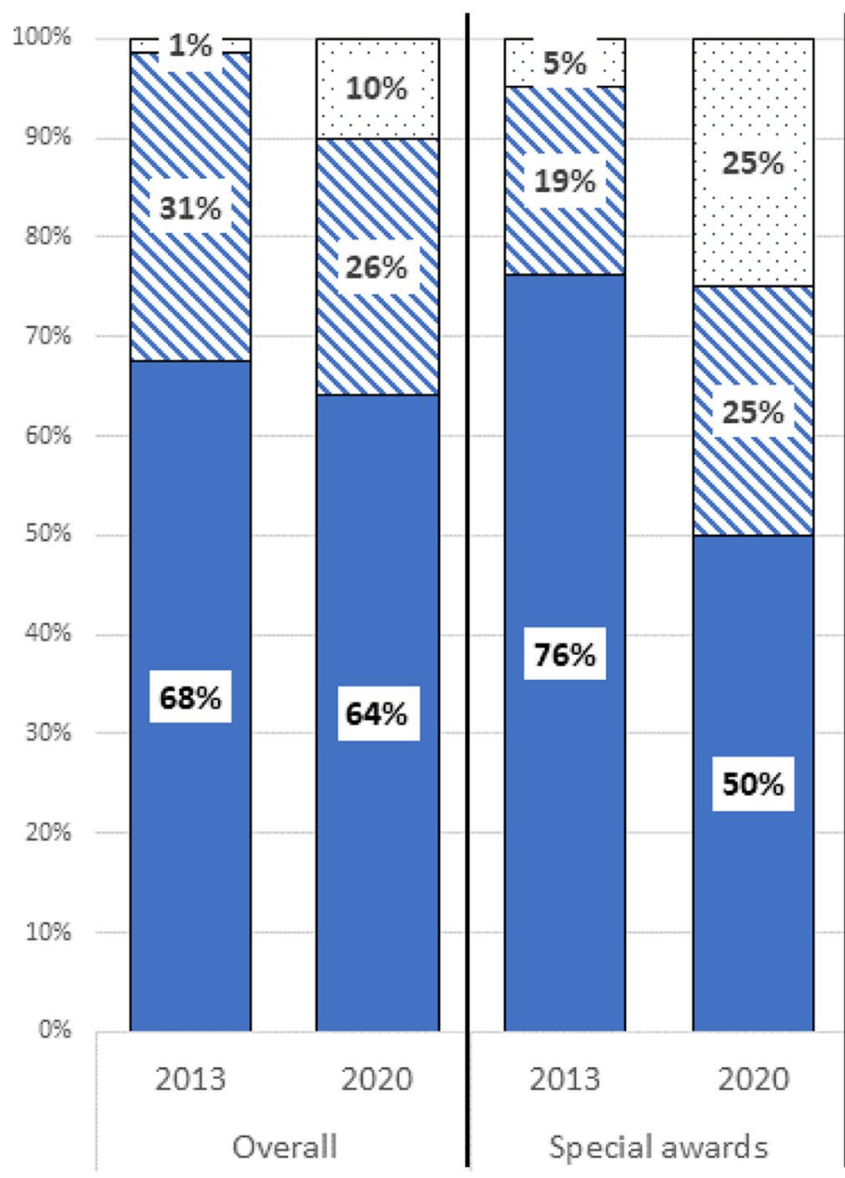

Fig. 3 The demographics of student participants in GEARSEF from 2013 to 2020, demographics of students receiving category awards (e.g. engineering, physics, behavioral sciences) and demographics of

a wide range of students at the local level of competition. Twenty teachers from cohorts 2 and 3 provided usable data from the post-fair survey from participating and nonparticipating students (another three did not provide surveys from students completing a project). This data was important for determining whether there were differences in demographics or attitudes as a result of participating in an S\&E fair project.

Across all teachers, students from Latinx and African American backgrounds as well as girls were proportionally represented among students completing a project (Table 7). Although teachers cannot control which students complete a project (particularly when they are optional), they were strongly encouraged to promote the participation of these over under-represented groups. In this data, all but one of the classrooms represented girls proportionally, $80 \%$ of classrooms had representative numbers of African-American students ( 16 classrooms out of 20 ), and $65 \%$ has representative numbers of Latinx students.

To further explore how demographics related to fair participation, we analysed the demographic characteristics of students in predicting who completed an S\&E fair projects

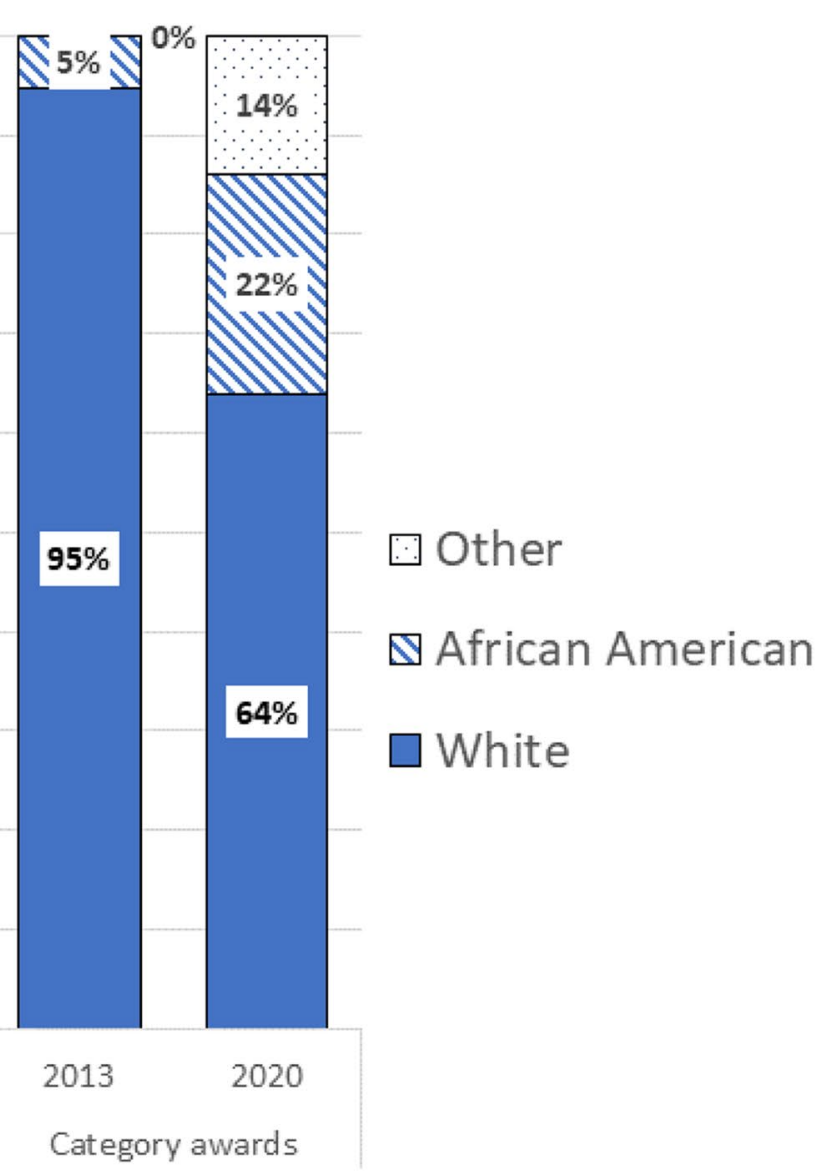

students winning special awards (named awards given across categories, such as awards funded by individual colleges). 'Other' race was predominantly Asian

using logistic regression, Table 8 . The only significant effect was grade level $(B=-0.435, p<0.001)$, where teachers with younger students seemed more likely to require all students to complete a project, while teachers with older students made the projects optional. For example, out of the 8 classes with data for sixth grade, $6(75 \%)$ had all students completing a project. In grades $7-9,30-45 \%$ of the classes required projects. Across grades 10-12, 26 classes provided data and just two required projects. Based on teacher report, these tended to be advanced or AP classes.

When looking at which students advance from the school to the regional fair, demographic variables had more pronounced effects (Table 9). Girls were $91 \%$ more likely than boys to advance from the school to regional fair $(B=0.645$, $p=0.025$ ). African-American students were $77 \%$ less likely than white students to advance $(B=-1.459, p<0.001)$. Finally, students whose mother had at least a college degree were $110 \%$ more likely to advance than other students $(B=0.755, p=0.033)$.

One possible explanation is that the school judges are biased against some students. Implicit bias affects teachers' 
Table 6 Teacher perceptions of the acceptability and effectiveness of S\&E Fairs and the project (scale: $0=$ Not at all true, $2=$ Somewhat true, $4=$ Very true)

\begin{tabular}{|c|c|c|}
\hline Scale/items & M & SD \\
\hline Acceptability (scale average) & 3.7 & 0.4 \\
\hline Our school has enough staff, time, and other resources to make the STEM-IQ Project benefit the school & 3.3 & 0.5 \\
\hline The STEM-IQ workshops held are worth the time it takes to attend & 3.8 & 0.4 \\
\hline Collaboration with faculty like the current project are helpful to my school & 4.0 & 0.2 \\
\hline Our school has enough staff, time and other resources to make a science and engineering fair benefit the students & 3.3 & 0.6 \\
\hline Organizing a science and engineering fair for my class or school will take a lot of time and effort & 3.4 & 0.7 \\
\hline The campus visits during the school year for students will be worth the time it takes to attend & 3.9 & 0.3 \\
\hline Organizing a science and engineering fair for my class or school is worth the time it takes to organise & 3.7 & 0.5 \\
\hline Collaborating with other teachers from my school will help me run a successful science fair & 3.9 & 0.2 \\
\hline I believe I will take away lasting benefits from participating in the STEM-IQ Project & 3.8 & 0.4 \\
\hline Effectiveness for students (scale average) & 3.4 & 0.5 \\
\hline Students' competence in science & 3.5 & 0.6 \\
\hline Students' motivation to understand science in depth & 3.4 & 0.6 \\
\hline Students' interest in science & 3.5 & 0.6 \\
\hline Students' belief in the importance of science & 3.4 & 0.6 \\
\hline Students' academic performance in science & 3.4 & 0.7 \\
\hline Female students' interest in science & 3.2 & 0.7 \\
\hline Racial/ethnic minority students' interest in science & 3.2 & 0.8 \\
\hline Intent to implement (scale average) & 4.0 & 0.2 \\
\hline I will mentor at least two students on their science fair projects this year & 4.0 & 0.2 \\
\hline I will implement a science and engineering fair following Intel ISEF rules at my school this year & 3.9 & 0.3 \\
\hline
\end{tabular}

perceptions and ratings of students from certain backgrounds (Starck et al., 2020), and studies of judgement or evaluation in the workplace suggest that bias against minoritised groups and girls may be common (Koch et al., 2015; Kraiger \& Ford, 1985). However, in many of these schools the judges and students were Black and from the same community. Further, rater bias may be expected to penalise girls, but that was not observed here. In sum, we cannot rule out rater bias, but we did explore other potential explanations in terms of differential access to materials and support for high-quality projects.

We asked students a few questions about their project experience in our survey. Very few (less than 10) reported working with a university lab on their project, so this was not likely a factor. Across the significant variables (races, mother education and gender), there were no differences in whether the students worked in a group or alone. Some differences were observed in sources of materials for their project. White students were more likely than Black or Latinx students to list local businesses or universities as a source of materials ( $10 \%$ vs. $5 \%$ for other groups; $\left.\chi^{2} p<0.01\right)$. Comparing girls and boys, girls were less likely than boys to list local businesses or universities as a source of materials (7\% vs. $11 \%, \chi^{2} p<0.05$ ), but girls were more likely to advance despite this difference.
The simplest explanation for much of these effects may come down to lack of judge training and the visual appeal of the project and its display. While judge training was given at the regional fair, this was not always the case at the local fairs, and our informal observations suggested that the design and attractiveness of displays was an important factor in scoring at the local fairs, where administrators or staff were likely to be the judges rather than professionals or scientists. As a result, flashy demonstration projects, as opposed to true scientific inquiry or engineering design, often won locally. In this case, race and mother's education may be confounded with socioeconomic resources such that Black students and students whose mothers have less education may not have access to attractive project materials. It may also be that some parents are more likely to get involved directly in the design of the project, leading to more sophisticated or attractive projects. Further research is needed on how access to resources influenced success and is differentially distributed among students by race or gender.

\section{Impact of Fair on Students Controlling for Pre-Fair Differences}

Our final research question focused on whether fair participation had the intended positive effects on students' attitudes 
Table 7 Proportional representation of students by gender and race who completed projects

\begin{tabular}{|c|c|c|c|c|c|c|c|c|}
\hline & \multirow[b]{2}{*}{ Survey $n$} & \multicolumn{3}{|c|}{ Classroom demographics } & \multirow[b]{2}{*}{ Project $n$} & \multicolumn{3}{|c|}{ Project participants ratio } \\
\hline & & $n, \%$ Black & $n, \%$ Latinx & $n, \%$ girls & & $n, \%$ Black & $n, \%$ Latinx & $n, \%$ girls \\
\hline \multirow[t]{2}{*}{ Teacher 1} & 17 & 3 & 1 & 6 & 12 & 2 & 0 & 4 \\
\hline & & $17.6 \%$ & $5.9 \%$ & $35.3 \%$ & & $16.7 \%$ & $0.0 \%$ & $33.3 \%$ \\
\hline \multirow[t]{2}{*}{ Teacher 2} & 34 & 12 & 1 & 20 & 30 & 9 & 1 & 18 \\
\hline & & $35.3 \%$ & $2.9 \%$ & $58.8 \%$ & & $30.0 \%$ & $3.3 \%$ & $60.0 \%$ \\
\hline \multirow[t]{2}{*}{ Teacher 3} & 39 & 17 & 1 & 23 & 37 & 17 & 1 & 23 \\
\hline & & $43.6 \%$ & $2.6 \%$ & $59.0 \%$ & & $45.9 \%$ & $2.7 \%$ & $62.2 \%$ \\
\hline \multirow[t]{2}{*}{ Teacher 4} & 30 & 11 & 1 & 15 & 29 & 11 & 1 & 14 \\
\hline & & $36.7 \%$ & $3.3 \%$ & $50.0 \%$ & & $37.9 \%$ & $3.4 \%$ & $48.3 \%$ \\
\hline \multirow[t]{2}{*}{ Teacher 5} & 37 & 2 & 3 & 13 & 5 & 0 & 0 & 2 \\
\hline & & $5.3 \%$ & $7.9 \%$ & $34.2 \%$ & & $0.0 \%$ & $0.0 \%$ & $40.0 \%$ \\
\hline \multirow[t]{2}{*}{ Teacher 6} & 60 & 43 & 5 & 36 & 31 & 22 & 2 & 18 \\
\hline & & $72.1 \%$ & $8.2 \%$ & $60.7 \%$ & & $71.0 \%$ & $6.5 \%$ & $58.1 \%$ \\
\hline \multirow[t]{2}{*}{ Teacher 7} & 35 & 19 & 0 & 19 & 18 & 10 & 0 & 7 \\
\hline & & $54.3 \%$ & $0.0 \%$ & $54.3 \%$ & & $55.6 \%$ & $0.0 \%$ & $38.9 \%$ \\
\hline \multirow[t]{2}{*}{ Teacher 8} & 48 & 41 & 3 & 30 & 5 & 5 & 0 & 3 \\
\hline & & $85.4 \%$ & $6.3 \%$ & $62.5 \%$ & & $100.0 \%$ & $0.0 \%$ & $60.0 \%$ \\
\hline \multirow[t]{2}{*}{ Teacher 9} & 32 & 19 & 4 & 19 & 32 & 19 & 4 & 19 \\
\hline & & $59.4 \%$ & $12.5 \%$ & $59.4 \%$ & & $59.4 \%$ & $12.5 \%$ & $59.4 \%$ \\
\hline \multirow[t]{2}{*}{ Teacher 10} & 30 & 9 & 1 & 16 & 29 & 8 & 1 & 15 \\
\hline & & $30.0 \%$ & $3.3 \%$ & $53.3 \%$ & & $27.6 \%$ & $3.4 \%$ & $51.7 \%$ \\
\hline \multirow[t]{2}{*}{ Teacher 11} & 35 & 3 & 9 & 22 & 35 & 3 & 9 & 22 \\
\hline & & $8.6 \%$ & $25.7 \%$ & $62.9 \%$ & & $8.6 \%$ & $25.7 \%$ & $62.9 \%$ \\
\hline \multirow[t]{2}{*}{ Teacher 12} & 57 & 23 & 4 & 39 & 24 & 10 & 1 & 18 \\
\hline & & $39.7 \%$ & $6.9 \%$ & $69.0 \%$ & & $41.7 \%$ & $4.2 \%$ & $75.0 \%$ \\
\hline \multirow[t]{2}{*}{ Teacher 13} & 34 & 5 & 4 & 23 & 34 & 5 & 4 & 23 \\
\hline & & $14.7 \%$ & $11.8 \%$ & $67.6 \%$ & & $14.7 \%$ & $11.8 \%$ & $67.6 \%$ \\
\hline \multirow[t]{2}{*}{ Teacher 14} & 36 & 11 & 1 & 21 & 23 & 5 & 0 & 11 \\
\hline & & $30.6 \%$ & $2.8 \%$ & $58.3 \%$ & & $21.7 \%$ & $0.0 \%$ & $47.8 \%$ \\
\hline \multirow[t]{2}{*}{ Teacher 15} & 34 & 19 & 0 & 22 & 34 & 19 & 0 & 22 \\
\hline & & $55.9 \%$ & $0.0 \%$ & $64.7 \%$ & & $55.9 \%$ & $0.0 \%$ & $64.7 \%$ \\
\hline \multirow[t]{2}{*}{ Teacher 16} & 38 & 16 & 3 & 20 & 33 & 15 & 3 & 17 \\
\hline & & $41.0 \%$ & $7.7 \%$ & $53.8 \%$ & & $45.5 \%$ & $9.1 \%$ & $51.5 \%$ \\
\hline \multirow[t]{2}{*}{ Teacher 17} & 40 & 8 & 1 & 22 & 32 & 7 & 1 & 18 \\
\hline & & $20.0 \%$ & $2.5 \%$ & $55.0 \%$ & & $21.9 \%$ & $3.1 \%$ & $56.3 \%$ \\
\hline \multirow[t]{2}{*}{ Teacher 18} & 38 & 6 & 2 & 21 & 5 & 0 & 1 & 3 \\
\hline & & $15.0 \%$ & $5.0 \%$ & $55.0 \%$ & & $0.0 \%$ & $20.0 \%$ & $60.0 \%$ \\
\hline \multirow[t]{2}{*}{ Teacher 19} & 35 & 25 & 4 & 18 & 17 & 13 & 0 & 11 \\
\hline & & $71.4 \%$ & $11.4 \%$ & $51.4 \%$ & & $76.5 \%$ & $0.0 \%$ & $64.7 \%$ \\
\hline Teacher 20 & 44 & 9 & 1 & 21 & 16 & 2 & 0 & 7 \\
\hline & & $20.5 \%$ & $2.3 \%$ & $47.7 \%$ & & $12.5 \%$ & $0.0 \%$ & $43.8 \%$ \\
\hline Total & & $37.8 \%$ & $7.2 \%$ & $55.6 \%$ & & $37 \%$ & $5 \%$ & $55 \%$ \\
\hline
\end{tabular}

Italics $=$ above or within 1.96 S.E. of total representation by percentage towards science and engineering. We compared three groups of students in terms of their science interest, self-efficacy and value perceptions: those who did not complete a project ('no project'), those who completed a project but did not advance to the regional fair ('not advanced') and those who did advance to the regional fair ('advanced'). For those no project students, efficacy and value actually decreased moderately during the school year $(d=-0.31$ and -0.82 , respectively). This is consistent with work showing that science attitudes tend to decline in junior high and high school 
Table 8 Logistic regression results for students completing a project

\begin{tabular}{lllllll}
\hline & \multicolumn{7}{l}{ Predicting } & whether student completed a project & & \\
\cline { 2 - 7 } & B & S.E & Wald & $d f$ & Sig & Exp(B) \\
\hline Sex & -0.087 & 0.200 & 0.188 & 1 & 0.665 & 0.917 \\
Race/ethnicity & & & & & & \\
$\quad$ African American & -0.162 & 0.203 & 0.640 & 1 & 0.424 & 0.850 \\
$\quad$ Latinx & -0.092 & 0.420 & 0.048 & 1 & 0.827 & 0.912 \\
Parent or guardian education & & & & & & \\
$\quad$ Father college degree & 0.020 & 0.217 & 0.008 & 1 & 0.928 & 1.020 \\
$\quad$ Mother college degree & 0.156 & 0.225 & 0.482 & 1 & 0.488 & 1.169 \\
Current performance: & & & & & & \\
$\quad$ Better than most & 0.039 & 0.209 & 0.034 & 1 & 0.853 & 1.040 \\
$\quad$ Don't know or worse & -0.016 & 0.334 & 0.002 & 1 & 0.961 & 0.984 \\
Grade level & -0.435 & 0.055 & 63.612 & 1 & $<0.001$ & 0.647 \\
Constant & 4.767 & 0.571 & 69.652 & 1 & $<0.001$ & 117.583 \\
\hline
\end{tabular}

Sex reference group was male. Race/ethnicity reference group was white. Parent education reference group was 'high school degree or less'. Performance reference group was 'About the same'. Smaller race/ethnicity groups were suppressed because they lacked statistical power. We used two logistic regressions rather than a multinomial model because for this variable we wanted to see if demographic variables predicted completing a project, regardless of whether it advanced
(Anderman et al., 1999; Conley et al., 2006; George, 2000). Not advanced students showed stable attitudes over the school year (which may actually be an encouraging result if the overall trend is that they would decline). Finally, advanced students showed substantial increases in all of the attitudes ( $d=0.32$ to 0.57 ). None of the attitudes differed between groups at pre-survey.

We ran ANCOVA analyses looking at the effect of participation in the S\&E fair, controlling for pre-fair attitudes. We also included classroom as a random-effects variable to control for the clustering effects of students nested in classrooms. Differences were found in all attitudes between no project, not advanced and advanced. For each of the three dependent variables, after controlling for pre-fair differences, no project students had the lowest interest, efficacy and values for science and engineering. Advanced students always had the highest means, Table 10.

\section{Impact on Students of Advancing to Regional Fair}

We were able to compare the perceptions of students whose projects did or did not advance to the regional fair (advanced vs. not advanced). Prior to the fair, we found no significant differences in the interest, efficacy or value of these students, suggesting that they had similar attitudes towards science and engineering. The results in Table 10 show that the advanced students ended up with significantly higher levels of interest, self-efficacy and utility values $(d=0.47$ to 0.72 ). When students were asked directly in individual survey items about their learning and changes in interest, students whose projects advanced reported learning important science content from their project $(d=0.91$ comparing advanced vs. not advanced) and that their project made them more interested in science or engineering $(d=0.80)$.

The transformative experiences scale (Pugh et al., 2010) was designed around three types of experiences: motivated use (including looking for opportunities to learn more), expanded perception (noticing connections of the topic to everyday life) and experiential value (a sense that they have learned something useful). Only students who completed a project completed this survey.

For all students completing a project, the highest ratings for transformative experiences were for motivated use $(\mathrm{M}=3.41, \mathrm{SD}=1.15$; scale $1-5)$. The lowest average ratings were for expanded perception $(\mathrm{M}=2.91, \mathrm{SD}=1.15)$. This suggests that completed science fair projects led to experiences that students liked to talk and learn more about their topic. They also saw the experience as valuable to them $(\mathrm{M}=3.03, \mathrm{SD}=1.10)$. See Table 11.

Between these two groups of students, we also found significant differences in all three types of transformative experiences ( $d=0.49$ to 0.67$)$. Although we cannot be certain whether it was the experience of being successful in their project or the topic itself (or being the kind of student who completes a high-quality project), this is certainly an encouraging finding for the value of science fairs.

\section{Limitations}

This data was collected as part of a program evaluation. Every effort was made to collect data from all teacher and student participants, but each level of data is limited to some 
Table 9 Logistic regression results for students advancing to the regional fair

\begin{tabular}{lrrrrrr}
\hline & \multicolumn{7}{l}{ Predicting } & whether project advanced to regional fair & \\
\cline { 2 - 7 } & \multicolumn{1}{c}{ B } & S.E & Wald & $d f$ & Sig & Exp(B) \\
\hline Sex & 0.645 & 0.289 & 4.993 & 1 & 0.025 & 1.907 \\
Race/ethnicity & & & & & & \\
$\quad$ African American & -1.459 & 0.372 & 15.371 & 1 & $<0.001$ & 0.233 \\
$\quad$ Latinx & 0.328 & 0.480 & 0.466 & 1 & 0.495 & 1.388 \\
Parent or guardian education & & & & & & \\
$\quad$ Father college degree & -0.119 & 0.315 & 0.143 & 1 & 0.705 & 0.888 \\
$\quad$ Mother college degree & 0.755 & 0.355 & 4.537 & 1 & 0.033 & 2.128 \\
Current performance: & & & & & & \\
$\quad$ Better than most & 0.355 & 0.293 & 1.471 & 1 & 0.225 & 1.426 \\
$\quad$ Don't know or worse & -0.126 & 0.507 & 0.062 & 1 & 0.803 & 0.881 \\
Grade & 0.053 & 0.074 & 0.507 & 1 & 0.477 & 1.054 \\
Constant & -2.645 & 0.739 & 12.813 & 1 & $<0.001$ & 0.071 \\
\hline
\end{tabular}

Sex reference group was male. Race/ethnicity reference group was white. Parent education reference group was 'high school degree or less'. Performance reference group was 'About the same'. Smaller race/ethnicity groups were suppressed because they lacked statistical power degree in terms of full sampling. Fair-level data was limited by whether students provided full demographic data when registering. The school and student participation numbers are complete.

Most teachers participating in the program also volunteered to participate in the research and, thus, provided their survey responses, but the sample is limited to teachers who self-selected to participate (or were strongly encouraged by their colleagues or administration). Student data may also not be fully representative even of the schools participating. Teachers varied in how much student data they provided, with some providing participant and nonparticipant (control) data as requested while others only provided participant data (i.e. surveys only for students who participated in the local fair). The practicality of program evaluation also limits the depth of data we were able to collect. Therefore, brief and unobtrusive data collection methods were used.
A limitation for the student participation data is that the program strongly encouraged teachers either to require a project for all students or to strongly encourage girls and minority students to participate. As a result, the proportion of students from underrepresented groups is likely higher in this sample than if the teachers had no encouragement to seek diverse student participation. It is important that organisations seeking to replicate this type of project also emphasise the importance of encouraging girls and underrepresented groups to participate in optional STEM-related activities.

\section{Discussion}

The NGSS (NRC, 2013) explain that students can only learn about scientific inquiry and engineering design by enacting those practices in authentic ways. S\&E fairs have been
Table 10 Comparison of students' science attitudes before and after the fair (Means, SDs in parentheses)

\begin{tabular}{|c|c|c|c|c|c|c|c|c|c|c|c|c|}
\hline & \multirow{2}{*}{\multicolumn{2}{|c|}{$\begin{array}{l}1-\text { No project } \\
(N=243)\end{array}$}} & \multirow{2}{*}{\multicolumn{2}{|c|}{$\begin{array}{l}2-\text { Not } \\
\text { advanced } \\
(N=464)\end{array}$}} & \multirow{2}{*}{\multicolumn{2}{|c|}{$\begin{array}{l}\text { 3-Advanced } \\
(N=82)\end{array}$}} & \multirow{2}{*}{\multicolumn{3}{|c|}{$\begin{array}{l}\text { ANCOVA } \\
(\text { cluster adjusted } d f)^{\text {a }}\end{array}$}} & \multicolumn{3}{|c|}{$\begin{array}{l}\text { Cohen's } d \text { for post } \\
\text { scores }\end{array}$} \\
\hline & & & & & & & & & & $1-2$ & $2-3$ & $1-3$ \\
\hline & Pre & Post & Pre & Post & Pre & Post & $F$ & $D f$ & Sig & & & \\
\hline Interest & $\begin{array}{c}2.92 \\
(0.66)\end{array}$ & $\begin{array}{c}2.85 \\
(0.63)\end{array}$ & $\begin{array}{c}2.84 \\
(0.67)\end{array}$ & $\begin{array}{c}2.90 \\
(0.68)\end{array}$ & $\begin{array}{c}3.00 \\
(0.67)\end{array}$ & $\begin{array}{c}3.21 \\
(0.65)\end{array}$ & 5.44 & $2,102.6$ & 0.006 & 0.08 & 0.47 & 0.56 \\
\hline Efficacy & $\begin{array}{c}3.79 \\
(0.85)\end{array}$ & $\begin{array}{c}3.51 \\
(0.93)\end{array}$ & $\begin{array}{c}3.64 \\
(0.91)\end{array}$ & $\begin{array}{c}3.62 \\
(0.92)\end{array}$ & $\begin{array}{c}3.84 \\
(0.97)\end{array}$ & $\begin{array}{c}4.13 \\
(0.81)\end{array}$ & 10.08 & $2,105.3$ & $<.001$ & 0.12 & 0.59 & 0.71 \\
\hline Value & $\begin{array}{c}3.58 \\
(0.82)\end{array}$ & $\begin{array}{c}3.38 \\
(0.87)\end{array}$ & $\begin{array}{c}3.66 \\
(0.83)\end{array}$ & $\begin{array}{c}3.66 \\
(0.83)\end{array}$ & $\begin{array}{c}3.75 \\
(0.89)\end{array}$ & $\begin{array}{c}4.18 \\
(0.59)\end{array}$ & 19.55 & $2,126.95$ & $<.001$ & 0.33 & 0.72 & 1.08 \\
\hline
\end{tabular}

The scale for each measure was 1-5 (anchors: not at all true, somewhat true, very true)

${ }^{a}$ Each model controls for pre-fair scores on that dimension as well as a random effect for classroom to account for clustering 
Table 11 Comparison of students' transformative experiences (all completed projects)

\begin{tabular}{|c|c|c|c|c|c|c|}
\hline \multirow[t]{2}{*}{ Attitudes } & \multirow{2}{*}{$\begin{array}{l}\text { Not Advanced } \\
(N=730)^{\mathrm{a}}\end{array}$} & \multirow{2}{*}{$\begin{array}{l}\text { Advanced } \\
(N=118)\end{array}$} & \multicolumn{4}{|c|}{ ANCOVA (cluster-adjusted $d f$ ) } \\
\hline & & & $F$ & $d f$ & Sig & Cohen's $d$ \\
\hline $\begin{array}{l}\text { I learned important things } \\
\text { about science or engi- } \\
\text { neering from my project }\end{array}$ & 3.18 & 4.22 & 22.75 & 1,475 & $<.001$ & 0.91 \\
\hline $\begin{array}{l}\text { My project made me more } \\
\text { interested in science or } \\
\text { engineering }\end{array}$ & $2.96(1.38)$ & $3.98(1.17)$ & 17.90 & 1,472 & $<.001$ & 0.80 \\
\hline Motivated use & $2.65(1.12)$ & $3.41(1.15)$ & 39.82 & $1,59.4$ & $<.001$ & 0.67 \\
\hline Expanded perception & $2.33(1.05)$ & $2.91(1.15)$ & 14.72 & $1,55.2$ & $<.001$ & 0.52 \\
\hline Experiential value & $2.49(1.09)$ & $3.03(1.10)$ & 19.16 & $1,60.3$ & $<.001$ & 0.49 \\
\hline
\end{tabular}

The scale for each measure was 1-5 (anchors: not at all true, somewhat true, very true)

${ }^{\text {a }}$ Sample size much larger because no data was lost to matching demonstrated to be effective strategies to provide these authentic experiences with science and engineering (Abernathy \& Vineyard, 2001; Koomen, et al., 2018; Miller et al., 2018; Paul et al., 2016; Sahin, 2013; Schmidt \& Kelter, 2017; Welsh et al., 2020). Our observation in the field was that students from low-resource schools or from minoritised backgrounds did not have the same opportunities to engage in meaningful S\&E fair experiences and to benefit from the possibilities these fairs offer for success, recognition and even scholarships. This is consistent with prior research that suggests that both school participation in S\&E fairs and students' project quality may be associated with socioeconomic status (Grinnell et al., 2020; Kook et al., 2020; Korkmaz, 2012; McComas, 2011). With the STEM-IQ program, our team sought to create a model of collaboration with teachers in low-resource schools that could be scaled to other contexts to support teachers implementing S\&E fairs in these contexts to provide a quality $S \& E$ fair experience.

Our research questions focused on the changes in the regional $\mathrm{S} \& \mathrm{E}$ fair system as well as changes to individual students as a result of their teacher's participation in STEMIQ. Thus, we assessed the positive impacts on students at the classroom level while also ensuring the regional data suggested that more diverse students were participating in (and winning) the regional fair. Teachers' attitudes towards the program and towards S\&E fairs were also studied as teacher beliefs about the efficacy and acceptability of interventions have been shown to influence their efforts to implement new strategies effectively (Harn et al., 2013; Lakin \& Shannon, 2015; O’Donnell, 2008).

Our first research question focused on the impact of the program on regional fair participation. There is scant research on the diversity of participants in S\&E fair programs (cf., Korkmaz, 2012), and only recently initiated programs tracking their population (Kook et al., 2020), so we used baseline and follow-up data to explore the diversity of the regional fair. The program overall was successful in increasing the number and quality of projects that were presented at the regional fair. The number and diversity of students participating and receiving awards greatly increased over the project period, which we feel can be attributed to the project team's efforts. Data collected since the end of funding directly to teachers indicates that although participation peaked in 2018, higher levels of participation have been maintained.

In their surveys, teachers reported beliefs that S\&E fairs can benefit all students, including those with limited resources or who do not already show enthusiasm for science. Teachers in our study seemed to have the positive attitudes and perceptions of $S \& E$ fairs as well as of the STEM-IQ program that are essential to high-quality implementation (Lakin \& Shannon, 2015; O'Donnell, 2008). This is consistent with previous work showing that teachers often hold high opinions of the value of S\&E Fairs (Grote, 1995). The high proportions of underrepresented groups and girls completing projects in most classrooms suggest that the program was successful in increasing the diversity of students participating at the local level, mirroring the participation at the regional level. The increase in the number of students from these groups who received awards at the regional fair also supports our claim that both the number and quality of projects from underrepresented groups increased.

In considering student participation in S\&E fairs, we hoped to find that, when projects were optional, students from different gender or racial/ethnic background were equally likely to complete a project. There are substantial gender and race differences in science interest that are associated with the gaps in participation in STEM careers (Catsambis, 1995; Krapp \& Prenzel, 2011; Oon et al., 2020) and if teachers did not make an effort to encourage a wide range of students to participate, we expected to find that these gender and race differences would be reflected in participation rates. We found no differences, which suggests there was equity in participating in the fairs. 
Unfortunately, significant differences in advancing to the regional fair were found for gender, race and mother's education, suggesting a possible route for future research into differences in the quality of projects that these students complete and/or judging disparities at the school fairs. Previous research and opinion surveys suggest that parental resources and access to science labs may give some students an unfair advantage in the competitions (Craven \& Hogan, 2008; Grinnell et al., 2018; Grote, 1995; Kook et al., 2020; Syer \& Shore, 2001). In our conversations with teachers, even with the support of the STEM-IQ program, they still struggled to mentor students to complete high-quality projects, and students did not always have access to the resources needed to carry out their desired investigations. The impact of mother's education (which often correlates to SES) may indicate that access to resources and parental support of projects is perpetuating inequities through the quality of projects completed, even when all students are actively engaged in projects. Indeed, recent work is exploring how the level of support and guidance from the school can mitigate the unfair advantage that more resourced students may have (Kook et al., 2020).

It should be noted that local fairs often struggled to recruit judges, and training was minimal. Therefore, the influence of untrained judges is unknown. Our informal observations suggested that the design and attractiveness of displays was an important factor in scoring at the local fairs and that flashy demonstration projects (as opposed to true scientific inquiry or engineering design) often won locally. Parent support would directly impact the materials available for making the display, and parents may even help design the display, leading to more attractive projects (McBride \& Silverman, 1988; Syer \& Shore, 2001). Recruiting knowledgeable judges or brief training for judges on how to identify a high-quality project could mitigate this effect (Rillero \& Zambo, 2011).

Our initial research questions focused on the system impacts of STEM-IQ as a PD program for teachers. However, we also wanted to explore if the projects had positive impacts on students that would both build teachers' positive attitudes towards fairs and achieve the intended effect on students. Much of the extant literature on science fairs studies only participants in the fairs (e.g. Abernathy \& Vineyard, 2001; Grinnell et al., 2020; Korkmaz, 2012; Sahin, 2013). One of the only studies to have a true control group failed to find any effects of fair participation on student knowledge of the scientific method and mixed results for attitudes (Yasar \& Baker, 2003).

We were able to collect a comparison group and to control for pre-fair differences in science and engineering attitudes in order to better assess the impact of S\&E fair participation on students independent of their initial predisposition towards science and engineering. Completing an S\&E fair project is only valuable when it has a lasting impact on students' attitudes towards science and engineering or on their learning. Although we were not able to directly measure impacts on achievement, students' perceptions of learning were assessed.

These quasi-experimental methods allowed us to explore the impact of completing S\&E fairs on student gains on attitudes underlying expectancy-value theory (Wigfield \& Eccles, 2000): science and engineering self-efficacy, interest and utility-value perceptions. Controlling for pre-existing differences in these attitudes, we found that students not completing projects actually showed declines in their science attitudes during the year. Students who completed projects maintained similar attitudes, while those whose projects advanced had substantial gains on all three variables. Based on the underlying theory and past research, we would expect these changes to support greater motivation for learning within the domain (Meyer et al., 2019). It could also support their interest in a STEM career and motivate them to pursue relevant opportunities (Guo et al., 2017).

While the observation of enhanced attitudes suggests durable impacts on student motivation, it is unknown whether this gain can be attributed to the experience of engaging with a quality project, from being the kind of student who completes a quality project, or some other factor. This research extends the evidence using pre- and post-tests with a control group to show S\&E fairs appear to increase positive attitudes towards science and engineering even during an age where students tend to have declining interest in STEM fields (Anderman et al., 1999; Conley \& Karabenick, 2006; George, 2000).

We also explored whether students reported that their projects provided a transformative experience that includes deeper engagement with science and perceiving connections to the student's academic and everyday life. The concept of transformative experiences (Pugh et al., 2010) is a relatively recent addition to the field and captures the degree to which a specific learning experience rises above the typical learning experience to spark an enduring interest in a subject. Anecdotes of success in S\&E fair often sound like transformative experiences (e.g., Welsh et al., 2020), and we wanted to assess the degree to which participants reported transformative experiences based on their S\&E fair projects.

The strongest area of transformation students reported overall was in motivated use, which reflects students connecting their project to learning in the classroom or to their extracurricular interests. Comparing students who presented projects only for the school fair to those who advanced, we found that advancing students had all types of transformative experiences, meaning they were engaged in thinking about their project, found connections in their everyday life and found their topic valuable. This suggests that fair projects do provide transformative experiences that can lead to enduring interest in a subject. 


\section{Conclusion}

The theory of action for this program was that encouraging all students to complete $S \& E$ fair projects and supporting the quality of projects would lead to an expansion of the number and diversity of students who are engaged and excited about science and engineering. Indeed, our findings suggest that students who complete projects and advance to the regional fair had the most positive outcomes in terms of attitude and transformative experiences. The overall strong representation of girls, African-American, and Latinx students suggests that, overall, the program had its intended effects in increasing the positive impact that $\mathrm{S} \& \mathrm{E}$ fairs have on all students in our region. The evidence considered as a whole supports the use of PD programs for teachers to introduce school-level S\&E fairs in order to positively impact students' attitudes towards science and engineering and to increase participation in a program that has transformative effects on its participants. This could ultimately broaden participation in science and engineering fields as S\&E fairs are cited as a source of initial engagement for some of those who enter STEM careers (Welsh et al., 2020; Yoho, 2015).

An interesting path for future research is to better understand why students whose projects advanced to the regional fair had better outcomes than those who only presented in the school fair. Did they land on a topic that sparked interest? Did they have the support of family or teachers to complete better projects or who suggested ways to deepen their knowledge? To some extent, our methods allow us to rule out differences in motivation or interest as causes of completing better-quality projects (and thus advancing to regional). Future research could explore the obstacles that students encounter in selecting projects that align with their interests and lead to successful projects (by fair standards). Such projects seem most likely to create transformative experiences and spark sustained interest in science and engineering for more students.

Acknowledgements This material is based on work supported by the National Science Foundation under Grant No. 1348368.

\section{Declarations}

Ethical Approval All procedures performed in studies involving human participants were in accordance with the ethical standards of the IRB Office of Auburn University. Protocol \#14-055 EP 1402.

Consent All teacher participants in the study received the approved IRB forms and explained the study procedures. Participation in the study was voluntary, and the identifiable materials were not published in this study. Student data was reported anonymously by educators and was, therefore, exempt.

Conflict of Interest The authors declare that they have no conflicts of interest.

\section{References}

Abernathy, T. V., \& Vineyard, R. N. (2001). Academic competitions in science: what are the rewards for students? The Clearing House, 74(5), 269-276.

Anderman, E. M., Maehr, M. L., \& Midgley, C. (1999). Declining motivation after the transition to middle school: schools can make a difference. Journal of Research \& Development in Education, 32(3), 131-147.

Akçöltekin, A. (2016). Investigation of the effect of training on the development of high school teachers' attitudes towards scientific research and project competitions. Educational Science: Theory \& Practice, 16(4), 1349-1380. https://doi.org/10.12738/estp.2016.4.0334

Aubusson, P., Griffin, J., \& Kearney, M. (2012). Learning beyond the classroom: implications for school science. In B.J. Fraser, K.G. Tobin, \& C.J. McRobbie, Second International Handbook of Science Education (Vol. 1, pp. 1123-1134). New York, NY: Springer.

Beier, M. E., Kim, M. H., Saterbak, A., Leautaud, V., Bishnoi, S., \& Gilberto, J. M. (2019). The effect of authentic project-based learning on attitudes and career aspirations in STEM. Journal of Research in Science Teaching, 56(1), 3-23. https://doi.org/10.1002/ tea. 21465

Bencze, J. L., \& Bowen, G. M. (2009). A national science fair: exhibiting support for the knowledge economy. International Journal of Science Education, 31(8), 2459-2483.

Bennett, J., Dunlop, L., Knox, K. J., Reiss, M. J., \& Jenkins, R. T. (2018). Practical independent research projects in science: a synthesis and evaluation of the evidence of impact on high school students. International Journal of Science Education, 40(14), 1755-1773. https:// doi.org/10.1080/09500693.2018.1511936

Bunderson, E. D., \& Anderson, T. (1996). Preservice elementary teachers' attitudes toward their past experience with science fairs. School Science and Mathematics, 96(7), 371-377.

Catsambis, S. (1995). Gender, race, ethnicity, and science education in the middle grades. Journal of Research in Science Teaching, 32(3), 243-257.

Century, J., Rudnick, M., \& Freeman, C. (2010). A framework for measuring fidelity of implementation: a foundation for shared language and accumulation of knowledge. American Journal of Evaluation, 31(2), 199-218. https://doi.org/10.1177/1098214010366173

Conley, A. M., Karabenick, S., Blazevski, J., Friedel, J., \& Pagni, D. (2006). Beyond achievement: motivation-related evidence from a partnership between a targeted project (TASEL-M) and a RETA (MSP-MAP) [technical report]. University of Michigan. http://mspnet-static.s3. amazonaws.com/Conley.pdf

Craven, J., \& Hogan, T. (2008). Rethinking the science fair. Phi Delta Kappan, 89(9), 679-680.

Cuevas, P., Lee, O., Hart, J., \& Deaktor, R. (2005). Improving science inquiry with elementary students of diverse backgrounds. Journal of Research in Science Teaching, 42(3), 337-357. https://doi.org/10.1002/tea.20053

Duschl, R. (2008). Science education in three-part harmony: balancing conceptual, epistemic, and social learning goals. Review of Research in Education, 32(1), 268-291.

Fortus, D. (2014). Attending to affect. Journal of Research in Science Teaching, 51(7), 821-835.

Furtak, E. M., Seidel, T., Iverson, H., \& Briggs, D. C. (2012). Experimental and quasi-experimental studies of inquiry-based science teaching: a meta-analysis. Review of Educational Research, 82(3), 300-329.

George, R. (2000). Measuring change in students' attitudes toward science over time: an application of latent variable growth modeling. Journal of Science Education and Technology, 9(3), 213-225.

Grant, L. (2007). CREST Awards Evaluation: impact study. Liverpool, UK: University of Liverpool Science Communication Unit. http://www. britishscienceassociation.org/crest-evaluation 
Grinnell, F., Dalley, S., \& Reisch, J. (2020). High school science fair: positive and negative outcomes. PLoS One, 15(2), 1-17. https://doi. org/10.1371/journal.pone.0229237.

Grinnell, F., Dalley, S., Shepherd, K., \& Reisch, J. (2018). High school science fair: student opinions regarding whether participation should be required or optional and why. PLoS One, 13(8), e0202320. https:// doi.org/10.1371/journal.pone.0202320

Grote, M. G. (1995). Science teacher educators' opinions about science projects and science fairs. Journal of Science Teacher Education, 6(1), $48-52$.

Guo, J., Marsh, H. W., Parker, P. D., Morin, A. J., \& Dicke, T. (2017). Extending expectancy-value theory predictions of achievement and aspirations in science: dimensional comparison processes and expectancy-by-value interactions. Learning and Instruction, 49, $81-91$.

Hampton, E., \& Licona, M. (2013). Examining the impact of science fairs in a Mexican-American community. Journal of Border Educational Research, 5(1), 99-112.

Harn, B., Parisi, D., \& Stoolmiller, M. (2013). Balancing fidelity with flexibility and fit: what do we really know about fidelity of implementation in schools? Exceptional Children, 79, 181-193.

Karabenick, S. A., \& Maehr, M. L. (2007). Tools for the evaluation of motivation-related outcomes of math and science instruction: final report to the national science foundation. Ann Arbor, MI: Motivation Assessment Project.

Kazdin, A. E. (1980). Acceptability of alternative treatments for deviant child behavior. Journal of Applied Behavior Analysis, 13, 259-273.

Koch, A. J., D’Mello, S. D., \& Sackett, P. R. (2015). A meta-analysis of gender stereotypes and bias in experimental simulations of employment decision making. Journal of Applied Psychology, 100(1), 128-161.

Kook, J. F., DeLisi, J., Fields, E. T., \& Levy, A. J. (2020). Approaches for conducting middle school science fairs: a landscape study. Science Educator, 27(2), 71-80.

Koomen, M. H., Rodriguez, E., Hoffman, A., Petersen, C., \& Oberhauser, K. (2018). Authentic science with citizen science and student-driven science fair projects. Science Education, 102(3), 593-644.

Korkmaz, H. (2012). Making science fair: how can we achieve equal opportunity for all students in science? Procedia-Social and Behavioral Sciences, 46, 3078-3082.

Koskey, K. L., Sondergeld, T. A., Stewart, V. C., \& Pugh, K. J. (2018). Applying the mixed methods instrument development and construct validation process: the transformative experience questionnaire. Journal of Mixed Methods Research, 12(1), 95-122.

Kraiger, K., \& Ford, J. K. (1985). A meta-analysis of ratee race effects in performance ratings. Journal of Applied Psychology, 70(1), 56.

Krapp, A., \& Prenzel, M. (2011). Research on interest in science: theories, methods, and findings. International Journal of Science Education, $33(1), 27-50$

Lakin, J. M., \& Shannon, D. M. (2015). The role of treatment acceptability, effectiveness, and understanding in treatment fidelity: predicting implementation variation in a middle school science program. Studies in Educational Evaluation, 47, 28-37.

Lakin, J. M., \& Wallace, C. S. (2015). Assessing teachers' use of inquiry methods in the middle school science classroom. Journal of Science Teacher Education, 26(2), 139-162. https://doi.org/10.1007/ s10972-014-9412-1

Lee, O., Hart, J. E., Cuevas, P., \& Enders, C. (2004). Professional development in inquiry-based science for elementary teachers of diverse student groups. Journal of Research in Science Teaching, 41(10), 1021-1043. https://doi.org/10.1002/tea.20037

McBride, J., \& Silverman, F. (1988). Judging fairs fairly. Science and Children, 25(6), 15-18. http://www.jstor.org/stable/43166731

McComas, W. F. (2011). Science fairs: a new look at an old tradition. The Science Teacher, 78(8), 34-38.

Meyer, J., Fleckenstein, J., \& Köller, O. (2019). Expectancy value interactions and academic achievement: differential relationships with achievement measures. Contemporary Educational Psychology, 58, $58-74$.

Miller, K., Sonnert, G., \& Sadler, P. (2018). The influence of students' participation in STEM competitions on their interest in STEM careers. International Journal of Science Education, Part B, 8(2), 95-114. https://doi.org/10.1080/21548455.2017.1397298

Minner, D. D., Levy, A. J., \& Century, J. (2010). Inquiry-based science instruction - what is it and does it matter? Results from a research synthesis years 1984 to 2002. Journal of Research in Science Teaching, 47(4), 474-496.

Mowbray, C., Holter, M. C., Teague, G. B., \& Bybee, D. (2003). Fidelity criteria: development, measurement, and validation. American Journal of Evaluation, 24(3), 315-340.

National Research Council. (2012). A framework for K-12 science education: practices, crosscutting concepts, and core ideas. The National Academies Press.

National Research Council. (2013). The next generation science standards. Washington, DC: The National Academies Press.

O'Donnell, C. L. (2008). Defining, conceptualizing, and measuring fidelity of implementation and its relationship to outcomes in K-12 curriculum intervention research. Review of Educational Research, 78(1), 33-84.

Oon, P. T., Cheng, M. M. W., \& Wong, A. S. L. (2020). Gender differences in attitude towards science: methodology for prioritising contributing factors. International Journal of Science Education, 42(1), 89-112.

Paul, J., Lederman, N. G., \& Groß, J. (2016). Learning experimentation through science fairs. International Journal of Science Education, 38(15), 2367-2387. https://doi.org/10.1080/09500693. 2016.1243272

Pugh, K. J. (2011). Transformative experience: an integrative construct in the spirit of Deweyan pragmatism. Educational Psychologist, 46(2), 107-121. https://doi.org/10.1080/00461520.2011.558817

Pugh, K. J., Linnenbrink-Garcia, L., Koskey, K. L., Stewart, V. C., \& Manzey, C. (2010). Motivation, learning, and transformative experience: a study of deep engagement in science. Science Education, 94(1), 1-28.

Reimers, T. M., Wacker, D. P., \& Koeppl, G. (1987). Acceptability of behavior interventions: a review of the literature. School Psychology Review, 16(2), 212-227.

Rillero, P., \& Zambo, R. (2011). Inside the science fair: the judge's perspective. Science Teacher, 78(8), 44-46.

Sahin, A. (2013). STEM clubs and science fair competitions: effects on post-secondary matriculation. Journal of STEM Education: Innovations \& Research, 14(1), 5.

Schmidt, K. M., \& Kelter, P. (2017). Science fairs: a qualitative study of their impact on student science inquiry learning and attitudes toward STEM. Science Educator, 25(2), 126-132.

Schwab, J. J., \& Brandwein, P. F. (1966). The teaching of science as enquiry. In J. J. Schwab \& P. F. Brandwein (Eds.), The teaching of science (pp. 3-103). Cambridge, MA: Harvard University Press.

Starck, J. G., Riddle, T., Sinclair, S., \& Warikoo, N. (2020). Teachers are people too: examining the racial bias of teachers compared to other American adults. Educational Researcher, 49(4), 273-284. https://doi.org/10.3102/0013189X20912758

Syer, C. A., \& Shore, B. M. (2001). Science fairs: what are the sources of help for students and how prevalent is cheating? School Science and Mathematics, 101(4), 206-220.

Tanol, G. (2010). Treatment fidelity: relation to treatment acceptability and change over time unpublished dissertation].University of Minnesota.

Wartinger, P. H. (1999). Student science projects and science fairs: how to maximize benefits to students and minimize burden to teachers [Unpublished master's thesis]. The College at Brockport.

Welsh, C., Hedenstrom, M., \& Koomen, M. H. (2020). Science fair was one of the highlights of my middle school life: using science fair to develop NGSS practices. The American Biology Teacher, 82(1), 43-48. https://doi.org/10.1525/abt.2020.82.1.43 
Wigfield, A., \& Eccles, J. S. (2000). Expectancy-value theory of achievement motivation. Contemporary Educational Psychology, 25(1), 68-81.

Wilson-Lopez, A., Sias, C., Smithee, A., \& Hasbún, I. M. (2018). Forms of science capital mobilized in adolescents' engineering projects. Journal of Research in Science Teaching, 55(2), 246270. https://doi.org/10.1002/tea.21418

Yasar, S., \& Baker, D. (2003, 2003). The impact of involvement in a science fair on seventh grade students. http://files.eric.ed.gov/ fulltext/ED478905.pdf
Yoho, R. (2015). How science fairs shaped my career. Science, $349(6255), 1578$.

Publisher's Note Springer Nature remains neutral with regard to jurisdictional claims in published maps and institutional affiliations. 